\title{
THE STATE OF GREEN SPACES IN KUMASI CITY (GHANA): LESSONS FOR OTHER AFRICAN CITIES
}

\author{
Collins ADJEI MENSAH \\ University of Cape Coast, Ghana
}

\begin{abstract}
Integrating green spaces such as parks and gardens into the physical landscape of cities has been identified to enhance the health and wellbeing of urban dwellers. This paper assesses the state of green spaces in Kumasi city (Ghana), once known as the garden city of West Africa. Using a case study approach, a mixture of qualitative research techniques were employed whilst a set of eight themes were put together to guide the assessment. In all, green spaces were found to be in poor state. With the exception of conservation and heritage theme, the remaining seven themes that were used for the assessment all found the green spaces to be in poor state. It is therefore recommended that there should be an attitudinal change towards the maintenance of green spaces, the application of a collaborative governance approach, and priority giving to green spaces in all development agendas by city authorities.
\end{abstract}

Key Words: green spaces, urban landscape, urban quality of life, Kumasi, Ghana, Africa.

\section{Introduction}

Urban areas are the fastest growing land cover type in the world. Small cities are becoming big whilst the number of megacities (cities with more than 10 million inhabitants) has increased nearly 10-fold since 1950 (United Nations 2008). With more than half of the world's population living in urban areas since 2008, future projections show that this trend will continue with Africa and Asia having the highest rate of urbanisation in the next four decades (Fuller and Gaston 2009, United Nations 2012). The rapid rate of urbanisation in the world coupled with over concentration of many activities in urban areas is now having devastating effects on the urban natural environment especially on urban green spaces (Baycan-Levent and Nijkamp 2009, Lafortezza et al. 2009, Cobbinah and Darkwah 2016). These urban green spaces consist of all public and private open spaces in urban areas, mostly covered by vegetation which are directly (e.g. active or passive recreation) or indirectly (e.g. positive influence on the urban environment) available for use (URGE-Team 2004). Examples of these spaces include public parks, gardens, playing fields, outdoor sports areas, urban trees, and allotments.

The benefits that green spaces offer to the development of cities cannot be over emphasized. A well planned and managed urban green space shows the proper functioning of cities and it also enhances the identity, livability and health condition of cities (Baycan-Levent and Nijkamp 2009). It has also been established that a city that has good designed green spaces epitomises good planning and management, a healthy environment for humans, vegetation and wildlife populations, and furthermore bestows pride on its citizenry and government (Adams and Leedy 1987, Johnston 1990, Godefroid 2001, Jim 2004). According to Ebenezer Howard through his garden city model, a city with many green spaces offers opportunities to enhance the social wellbeing and recreational activities of city dwellers through frequent contact with such spaces (Howard 1902).

Despite the numerous benefits that these spaces offer to support the development of cities and the wellbeing of urban dwellers, studies have shown that most of these spaces in the global 
south are fast disappearing (Singh et al. 2010, Gomes and Moretto 2011, Cobbinah and Darkwah 2016). The exigencies of addressing poverty, providing the basic needs and other pressing human needs often overshadow the environmental concerns of many countries in the global south, especially those in Africa (Marcotullio 2001, Bolnick et al. 2006). In some African countries such as Nigeria, Senegal, Sierra Leone, Cote D'Ivoire and Ghana, studies show that green spaces are not much valued as they are often cleared to make way for many human activities (Abegunde et al. 2009, Fuwape and Onyekwelu 2011, Adjei Mensah 2014a). As a result of this, green spaces now occupy a small proportion of the landmass of many urban areas in Africa. For instance, a study by MacConnachie et al. (2008) in South Africa found green spaces occupying less than 10 per cent of the land area of several towns. In Lagos (Nigeria), it has been revealed that less than 3 per cent of the total land of the city is now covered by green spaces (Oduwaye 2013). Furthermore, in cities such as Cairo and Alexandria (Egypt), Luanda (Angola), Mogadishu (Somalia), Monrovia (Liberia), and Kumasi and Accra (Ghana), green spaces in a form of public parks and gardens cover insignificant proportion of the total landmass (Economist Intelligence Unit 2011, Adjei Mensah 2014a).

This deteriorating condition of green spaces in many African cities is happening at a time where there is much emphasis on concepts such as sustainable urban development and resilient cities which strongly support the integration of green spaces into city's physical landscape (Jabareen 2006, Desouza and Flanery 2013). This makes researching into the state of green spaces in the context of Africa critical and tenable to find possible ways to improve the declining condition of such spaces. But regrettably there is a paucity of studies on the state of green spaces in Africa. Previous studies have broadly looked at green spaces from the perspective of urbanisation, climate change and the role of such spaces in urban development without paying particular attention to their state especially in the context of Africa where such spaces are under severe threat (MacConnachie et al. 2008, Abegunde et al. 2009, Rabare et al. 2009, Ward et al. 2010, Kithiia and Lyth 2011, Cobbinah and Darkwah 2016). It was therefore to bridge this knowledge gap that this study was undertaken using Kumasi city in Ghana, which was once the garden city of West Africa as a case study.

The aim of this paper is to assess the state of urban green spaces in Kumasi and to draw key lessons to enhance the situation in the city and other African cities. The state of green spaces in this paper refers to the overall condition of green spaces in a given area by looking at a variety of themes or variables to draw conclusions. The paper makes significant contributions in different ways. First, it brings out some of the hidden issues behind the current state of urban green spaces in Africa for policy makers and city authorities to take informed decisions on them. Second, it provides an assessment framework on the state of urban green spaces which can be replicated in the context of Africa and elsewhere. It also highlights the relationships of some themes or variables associated with the state of green spaces and how poor attention to such relationships can have consequences on the overall state of green spaces.

\section{Theoretical perspective: Ideal green spaces}

There is a growing debate on what factors or themes should be used to assess the state of green spaces. One group of scholars believed in using solely quantitative means to assess the state of green spaces (Kuchelmeister 1998, Fraser 2002, Barbosa et al. 2007, Wang 2009). Their reason is based on the fact that this approach helps to know the total amount of green spaces available for each individual within a given area and also to quantify the total green space land area required to satisfy the needs of a group of people. Green space per capita (normally in square metres " $\mathrm{m}^{2 \prime}$ ), time and distances to green spaces often serve as major indicators for this group of scholars. Based on this idea, the World Health Organisation (WHO) and the Food and Agricultural Organisation (FAO) recommend a minimum of $9 \mathrm{~m}^{2}$ of green space per city dweller as appropriate for urban areas (Kuchelmeister 1998). Sukopp et al. (1995) and Wang (2009) have observed that the green space standard that many countries in 
the global north tend to adopt fall within $20 \mathrm{~m}^{2}$ of park area per capita. The European Environmental Agency recommends that for a green space to be in good state urban residents should have access to urban green spaces (e.g. urban parks) within a walking distance of 15 minutes, which is approximately 900 metres (Barbosa et al. 2007). A standard of $10 \mathrm{~m}^{2}$ green space per urban dweller is also recommended in Bangkok (Fraser 2002). Critics of this quantitative approach have raised concerns about it being too narrow, rigid, and over-emphasizing on only access to green spaces without given attention to other essential features that also contribute to enhancing the state of green spaces (Centre for Urban \& Regional Ecology 2002, Pauleit et al. 2003).

Contrary to the quantitative school of thought is another group of scholars who believed that taken into account the broad nature of green spaces, a blend of qualitative and quantitative features or themes have to be looked at in order to appropriately assess the state of green spaces. Among this group of scholars are Williams and Green (2001) who have found out that an ideal urban green space should have the following qualities: cleanliness, safety, accessibility and quietness. A study in UK by Dunnet et al. (2002) showed various characteristics that a good conditioned urban green space should have. These characteristics included availability of recreational facilities (e.g. sports facilities), good access, comfort (e.g. toilet, seats and shelter), natural element (wildlife, vegetation etc.), presence of staff and inclusiveness. Gobster and Westphal (2004) pointed out cleanliness, naturalness, aesthetics, safety, access and appropriateness of development as among the characteristics that an urban green space (such as parks, gardens and play grounds) which is in good state should possess. Community involvement in planning, user satisfaction, equitable access, marketing, conservation and heritage, and safety have been observed to also be some of the key features of good conditioned urban green spaces (Harnik 2004, Plymouth City Council 2009). The Green Flag Award which is a pristine award given to parks and other green spaces that are in good condition and well managed in UK has the following as its criteria: cleanliness, maintenance, facilities, care of historical heritage, environmentally sensitivity management, community participation, good management plan, conservation and attractiveness (The Urban Green Spaces Taskforce 2002). Looking at the above two broad views on the state of green spaces it can be said that assessing the state of green spaces is quite cumbersome as there is no universally accepted criteria to follow. However, in doing this one has to be more cautious and look at a range of themes (both quantitative and qualitative in nature) that broadly look at green spaces from different perspectives to make the assessment more comprehensive.

Relying on the ideas from the literature, a set of 8 themes was put together to assess the state of green spaces in Kumasi. These themes included accessibility, attractiveness, comfort, safety, conservation and heritage, maintenance, publicity, and community participation. They were adapted due to their broad scope in covering a wider spectrum of issues surrounding the development of green spaces and the vital role that each of them plays to enhance the state of green spaces. The selected themes were therefore used to develop a model to structure the investigations and the subsequent analysis in this paper (Fig. 1).

\section{Materials and Methods}

The study was undertaken in Kumasi, the second city of Ghana. The rational for selecting Kumasi was that it represents most of the issues facing urban green spaces in Africa such as rapid depletion of green spaces and unsustainable nature of these spaces (Adjei Mensah $2014 \mathrm{~b}$ ). Kumasi was built on the garden city model that supports the incorporation of many green spaces into cities physical landscape (Adarkwa and Owusu-Akyaw 2001, Quagraine 2011). The 1945 city plan of Kumasi, the Kumasi Planning Scheme between 1963 and 1988, and other planning schemes that underlie the physical development of Kumasi dedicated substantial part of the city's landmass to green spaces (Quagraine 2011). In 1960's, the city gained the accolade "the Garden city of West Africa" mainly because of the presence of many 


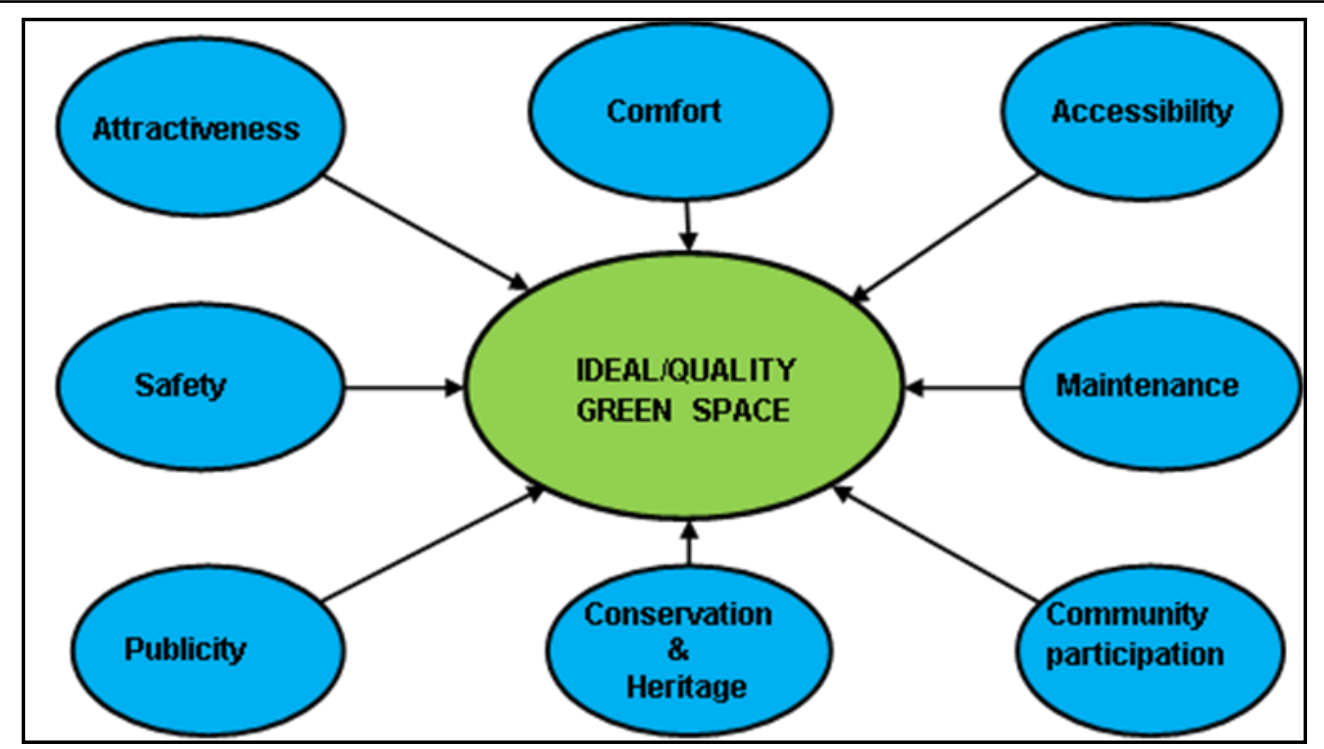

Fig. 1 - Themes for assessing the state of green spaces Source: Authors construct (2014)

well planned green spaces interspersing with physical land developments (Geurts 2009, Quagraine 2011). During that period over 60 per cent of the land area of the city was covered with green spaces, but since 2005 concerns have been raised about the city losing most of its green spaces (Tontoh 2011).

The city has a total population of just over 2 million making it the second largest city in Ghana (Ghana Statistical Service 2012). Kumasi falls within the moist semi-deciduous vegetation zone of Ghana which has favourable soil conditions that support farming and green vegetation. Five neighbourhoods (Patasi, Danyame, Ahodwo, Nhyiaso and Amokom) were selected for the study (Fig. 2). This was done in consultation with the Department of Parks and Gardens, the official body in charge of green spaces in Kumasi. They were selected on the basis that they harbour most of the green spaces in Kumasi and they are well noted for their greenery. In addition to this, the green spaces in the central business district and other vantage points were used as another case.

A combination of descriptive and explanatory case study approaches was used in the study. This enabled the study to describe the state of urban green spaces of Kumasi in their natural context and it gave possible explanation for such condition (Yin 2003, Hancock and Algozzine 2006). The study was purely qualitative and this was due to the nature of the study which demanded much information to know the true state of green spaces in Kumasi. In view of that it made use of a blend of qualitative methods such as in-depth interviews, focus group discussions, personal observations, and documentary and archival data, as recommended by Yin (2003). Four categories of people constituted the study's target population. These were the residents of the selected neighbourhoods, city authorities, opinion leaders and officials of allied bodies on green spaces. The selection of the respondents was based on theoretical or purposive sampling technique (Mills et al. 2010). They were selected based on the roles they play on green spaces. The city authorities serve as policy makers on green spaces, the allied bodies on green spaces manage these spaces whilst opinion leaders and the residents serve 
as users of the green spaces. In all, 30 in-depth interviews were conducted for key informants which included opinion leaders, city authorities, and representatives of allied bodies on green spaces. Almost all the key informants had tertiary educational background with some having Higher National Diploma (HND), university degree, and master's qualifications. They fell within middle and high income category, and were mostly professionals holding reputable positions in government and private institutions.

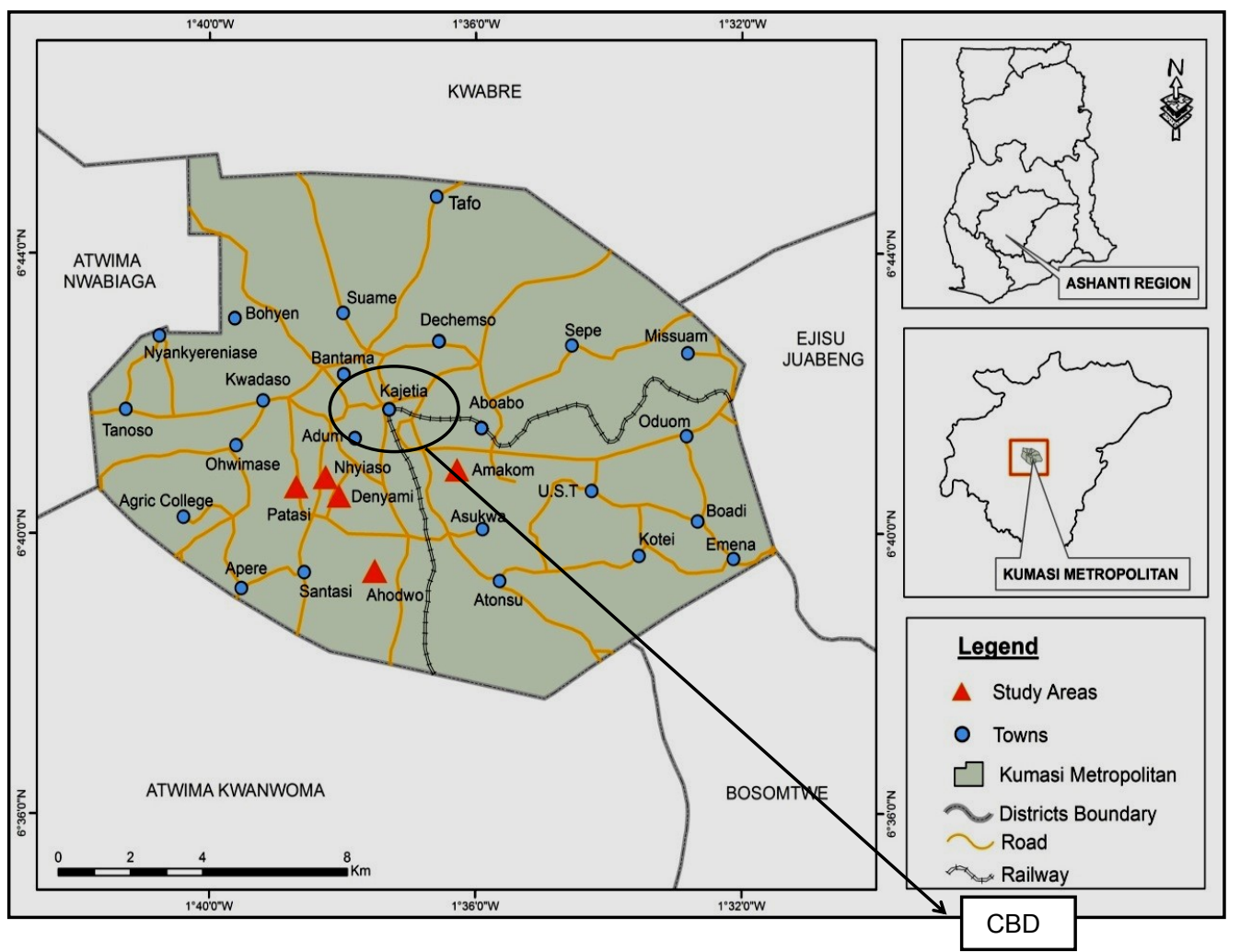

Fig. 2 - Kumasi city and the selected sites for the study

Source: Department of Geography and Regional Planning, University of Cape Coast (2013)

Aside the in-depth interviews, 10 focus group discussions (FGDs) were undertaken in the five (5) selected neighbourhoods. In each of the five (5) neighbourhoods, two (2) focus group discussions were done, one for the youth (18-45 years old) and one for the elderly (46 years old and above). This was done to get the views and experiences of both the young and the old on green spaces in order to draw informed conclusions. Each of the focus groups had participants ranging from 7 to 10. The participants of the FGDs who were residents of the selected neighbourhoods largely had basic and high school educational qualifications. They were mainly low income earners who engage in petty trading and artisanal jobs such as dress making, carpentry, plumbing and bakery. The differences in socio-economic background of the respondents (the residents and key informants) made them not to have the same value for green spaces. Numerous personal observations sessions were also undertaken on various green spaces to have first-hand information about the state of those spaces. For clarity and easy assessment, the eight (8) adapted themes already mentioned above were further 
operationalised to come up with specific indicators to suit the African context (the situation in Ghana) and also to guide the study (Table 1).

Indicators to assess the state of green spaces

Table 1

\begin{tabular}{|l|l|}
\hline THEME & \multicolumn{1}{|c|}{ INDICATOR } \\
\hline Attractiveness & $\begin{array}{l}\text { Presence of signage, well grown grasses, walkways, free from litter and } \\
\text { animal fouling, availability of dustbins, absence of unpleasant smell }\end{array}$ \\
\hline Comfort & $\begin{array}{l}\text { Availability of seats, playing facilities, toilet facilities } \\
\text { Serene environment }\end{array}$ \\
\hline Accessibility & $\begin{array}{l}\text { Enough availability of green spaces (minimum of } 9 \mathrm{~m}^{2} \text { green space per } \\
\text { city dweller as recommended by WHO) } \\
\text { Proximity to green spaces (public parks and gardens) of at least 20 } \\
\text { minutes' walk to a public park or garden }\end{array}$ \\
\hline Safety & $\begin{array}{l}\text { Free from vandalism, criminal attacks } \\
\text { Not used as hide outs for criminals } \\
\text { Availability of first aid, availability of lights at night }\end{array}$ \\
\hline $\begin{array}{l}\text { Conservation } \\
\text { and heritage }\end{array}$ & $\begin{array}{l}\text { Availability of historical/cultural artefacts on green spaces } \\
\text { Variety of plant and animal species }\end{array}$ \\
\hline Maintenance & $\begin{array}{l}\text { Absence of spoilt facilities } \\
\text { Facilities functioning for their purpose } \\
\text { Regular mowing of grasses and shaping of trees and flowers }\end{array}$ \\
\hline Publicity & $\begin{array}{l}\text { Promoting or marketing green spaces through mediums such as print and } \\
\text { electronic media, leaflets, and websites to attract visitors and educate } \\
\text { them as well }\end{array}$ \\
\hline $\begin{array}{l}\text { Community } \\
\text { participation }\end{array}$ & $\begin{array}{l}\text { Involving neighbourhood residents in green space conservation activities } \\
\text { such as tree planting exercise and community gardening }\end{array}$ \\
\hline
\end{tabular}

Source: Author's fieldwork (2013)

\section{Results and Discussion}

This section critically discusses the state of green spaces, it show the importance of the themes that were used for the assessment and it brings out the association or relationships that were found to exist between the themes.

\section{Access to green spaces in Kumasi}

Easy access to green spaces such as public parks is an important motivational factor that has been observed to encourage visitors to use such places in urban areas (Barbosa et al. 2007). In assessing the accessibility to green spaces in Kumasi, the per capita green space of the area was first calculated using WHO's minimum standard of $9 \mathrm{~m}^{2}$ green space per city dweller as a benchmark (Kuchelmeister 1998, Sanesi and Chiarello 2006, Fuady and Darjosanjoto 2012). There was scant information about the quantity of green spaces in the study area so some deductions were made from the 2010 estimated total amount of open spaces in Kumasi which was of 2375.4 hectares (Ministry of Lands and Natural Resources 2010). This figure comprises many different spaces other than green spaces so further enquiry was undertaken to address the matter. A study by Tontoh (2011) and data from the Kumasi Metropolitan Assembly confirmed that green spaces occupy about 40 per cent of the total amount of open spaces in the area which is of 2375.4 hectares. Taking into account the latest population of 
Kumasi of 2035064 inhabitants (Ghana Statistical Service 2012), an estimated $4.7 \mathrm{~m}^{2}$ green space per city dweller was obtained. The above estimations showed that the per capita green space in Kumasi $\left(4.7 \mathrm{~m}^{2}\right)$ is far below the minimum green space standard recommended by WHO $\left(9 \mathrm{~m}^{2}\right)$ as illustrated in Fig. 3.

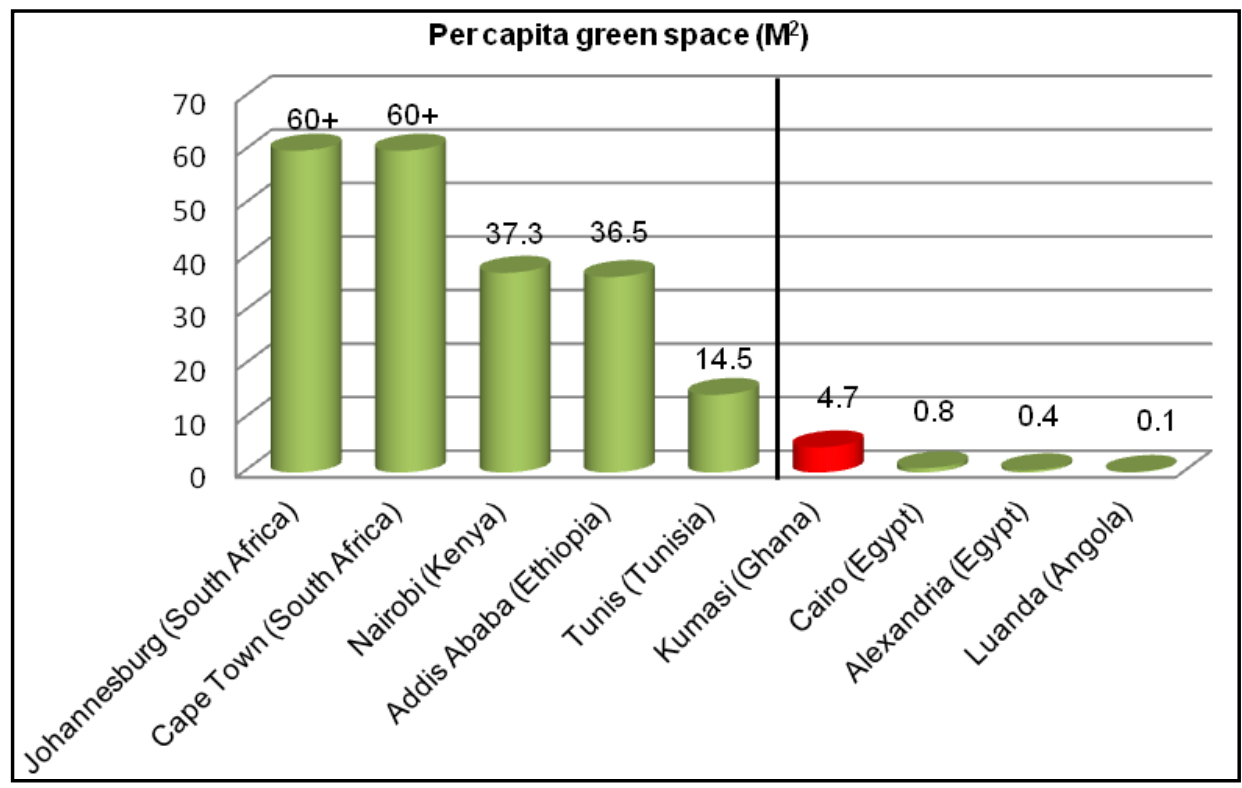

Fig. 3 - Green space per city dweller of Kumasi in the context of Africa Source: Economist Intelligence Unit (2011)

When compared to some cities in Africa, such as Johannesburg (South Africa), Nairobi (Kenya), and Addis Ababa (Ethiopia), the city's per capita green space lag behind greatly. Looking at these statistics, Kumasi needs more than $4 \mathrm{~m}^{2}$ green spaces to augment its per capita green space capacity to meet the WHO's minimum standard and to have enough green spaces for its residents. This position of poor access to green spaces does not befits Kumasi given its track record of being a notable garden city in the past and its advantageous geographical location in Africa where there are favourable soil and vegetation conditions that support the green spaces (Geurts 2009, Quagraine 2011). Similar findings came out in a study by Nyantakyi-Frimpong et al. (2016) which found poor access to green spaces (such as urban farmlands) a problem in the Greater Accra Region of Ghana due to limited land made available for such spaces in urban areas.

Proximity to the green spaces especially public parks by way of walking distance was also assessed. Unlike other cities such as Sheffield, Madrid, Paris, Milan, Brussels and Glasgow where public green spaces such as parks and gardens have been found to be within 15 minutes walking distance (Stanners and Bourdeau 1995, Barbosa et al. 2007), in Kumasi it takes approximately 50 to 60 minutes for one to have access to a natural public park. This came up through the interactions with the residents of the selected neighbourhoods and the personal observations that were carried out. It was found out that most of the neighbourhoods in Kumasi do not have their own parks so they have to travel longer distances to use the ones in other neighbourhoods. The current level of accessibility was observed to discourage the residents from using many parks in Kumasi. This is in consonance with the findings of Abkar et 
al. (2010) where poor access to green spaces was among the major obstacles that discouraged residents from using urban parks.

\section{Attractiveness and maintenance of green spaces}

The high level of attractiveness of green spaces such as parks and gardens is very important since it gives a good first impression to visitors and it encourages subsequent visits to the parks (van Herzele and Wiedemann 2003). Concerns on the attractiveness of green spaces featured prominently in the in-depth interviews and the focus group discussions. Issues of absence of signage, walkways and poor grown grasses on several parks and gardens in Kumasi strongly came up. Many of the parks were bare not having grasses on them. The untidy nature of many parks and its accompanying bad odour was another major issue. Specific parks and gardens such as Kumasi Children's Park, Adehyeman Gardens, Abbey's Park and Fante Newtown Park were found to have a filthy environment. The respondents (opinion leaders, city authorities and residents) expressed worries about the presence of many used polythene bags, solid waste and fouling of animals such as cattle, goats and sheep in the parks. Personal observations on some of the parks in Kumasi confirmed the seriousness of litters and the unpleasant odour (Fig. 4).

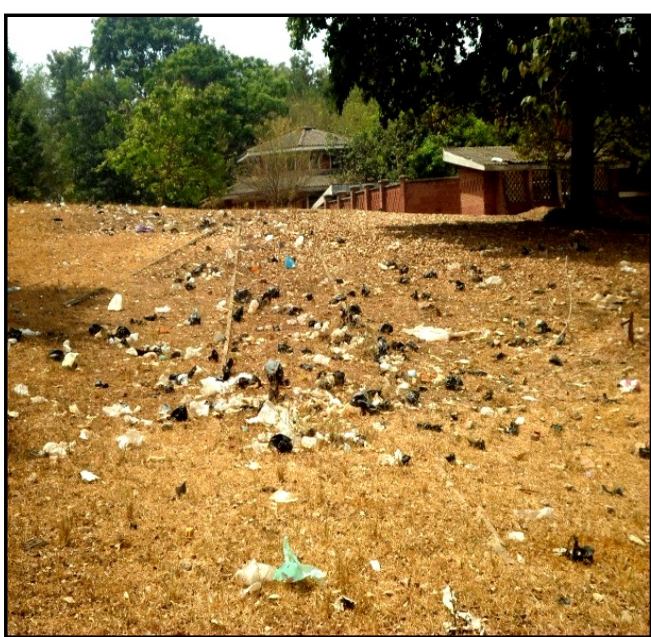

Kumasi Children's Park

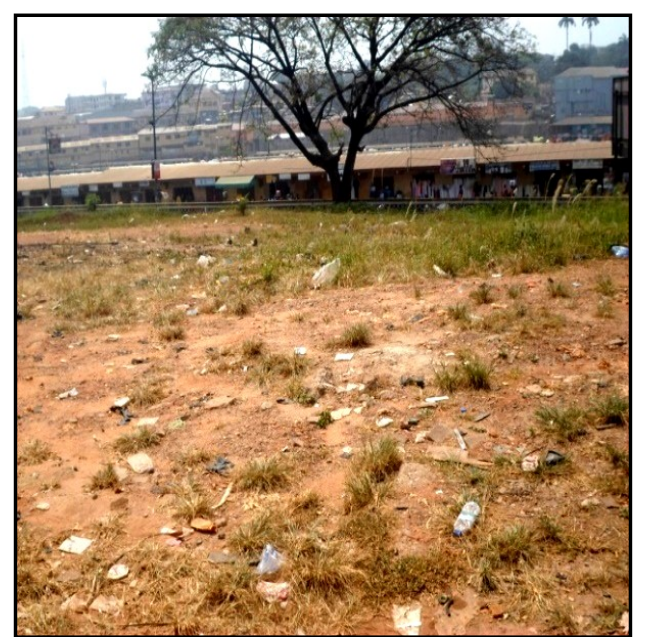

Adehyeman Gardens

Fig. 4 - The poor level of cleanliness on some parks in Kumasi Source: Author's fieldwork (2013)

Portions of some parks were even turned into refuse dumps. This was influenced by poor provision of garbage bins in the parks and gardens (Table 2). One of such parks was the Kumasi Children's Park. The normal norm is that garbage bins have to be provided in the various parks and gardens, and to be frequently emptied to keep the sanitation condition of such places good but this arrangement was found not to be properly handled by the Department of Parks and Gardens due to financial constraints. This problem was exacerbated by the poor culture of waste disposal by the general public. It was found that the general public were of the view that keeping the green spaces clean and tidy is the sole responsibility of the city authorities and thus it indiscriminately litter these places. This observation supports the findings of Fuwape and Onyekwelu (2011) on some parks and gardens in African cities such as Ibadan, Lagos, Kano and Kaduna (Nigeria), Freetown (Sierra Leone) and Accra (Ghana) where 
most of the parks were engulfed with much filth while some portions were even converted into refuse dumps.

This situation does not only substantially impinge detrimentally on the attractiveness of green spaces, but it has serious health implications for the visitors who use the parks for recreation. It makes such places common grounds for the contraction of diseases such as malaria and cholera which are associated with unhygienic environmental conditions. It also makes it difficult for common activities that often take place in parks such as sitting, lying and sleeping on grasses to be undertaken. Based on the indicators of the attractiveness theme, it can be said that the level of attractiveness of green spaces in Kumasi was poor (Table 2). It was the

Summary of the respondents overall views on the attractiveness of green spaces in Kumasi

\begin{tabular}{|c|c|c|c|c|c|c|}
\hline & & & Indicator & & & \\
\hline & Signage & Walkways & FFL \& $A^{*}{ }^{*}$ & US $^{* *}$ & WGG*** & Dustbins \\
\hline $\begin{array}{l}\text { Adehyeman Gardens } \\
\text { good }\end{array}$ & Poor & Poor & Poor & Poor & Poor & Fairly \\
\hline $\begin{array}{l}\text { Kumasi Children's } \\
\text { Park }\end{array}$ & Poor & Poor & Poor & Poor & Poor & Poor \\
\hline Ridge Park & Poor & Poor & Poor & $\begin{array}{l}\text { Fairly } \\
\text { good }\end{array}$ & Poor & Poor \\
\hline $\begin{array}{l}\text { Parks and Gardens } \\
\text { (Patasi) }\end{array}$ & Good & Good & $\begin{array}{l}\text { Fairly } \\
\text { good }\end{array}$ & Good & Good & Fairly good \\
\hline $\begin{array}{l}\text { Fante Newtown } \\
\text { Park }\end{array}$ & Poor & Poor & Poor & Poor & $\begin{array}{l}\text { Fairly } \\
\text { good }\end{array}$ & Poor \\
\hline Kumasi Zoo & Good & Good & $\begin{array}{l}\text { Fairly } \\
\text { good }\end{array}$ & Poor & Poor & Good \\
\hline Abbey's Park & Poor & Poor & Poor & Poor & Poor & Poor \\
\hline $\begin{array}{l}\text { KNUST Botanical } \\
\text { Gardens }\end{array}$ & Good & $\begin{array}{l}\text { Fairly } \\
\text { good }\end{array}$ & $\begin{array}{l}\text { Fairly } \\
\text { good }\end{array}$ & Good & Poor & Good \\
\hline Lawns at the CBD & Poor & $\begin{array}{l}\text { Fairly } \\
\text { Good }\end{array}$ & Poor & Poor & Poor & Poor \\
\hline
\end{tabular}

${ }^{\star} F F L$ \& AF: Free from litter and animal fouling; ${ }^{* *} U S$ : Unpleasant smell; ${ }^{* \star * W G G: ~ W e l l ~ g r o w n ~}$ grasses

Source: Author's fieldwork (2013)

KNUST Botanical Gardens, Parks and Gardens at "Patasi" and to some extent the Kumasi Zoo that looked quite attractive. These places had signage, walkways, well grown grasses and some available garbage bins. However, on the remaining parks these facilities were missing. In Abbey's Park, Kumasi Children's Park, and Fante Newtown Park for instance, the situation was 
worse as these places virtually have no facilities to make them attractive. The overall assessment of the attractiveness of green spaces in Kumasi is shown in Table 2.

Drawing on the findings of the attractiveness of green spaces, the study found a relationship to exist between this and the maintenance of green spaces in Kumasi. Poor maintenance was found as the root cause for the absence of several facilities on the green spaces to make them unattractive. Interviews with the Kumasi city authorities revealed the alienation or abandonment of some parks for several years without any form of maintenance work undertaken on them. The Kumasi Children's Park, Abbey's Park, and Fante Newtown Park were among the major parks that were found in such situation. An official of the Department of Parks and Gardens commented extensively on the broken down facilities in many parks, and the poorly maintained grasses, lawns, trees and shrubs in the CBD and along the principal streets of Kumasi. Fig. 5 provides photos showing the poor level of maintenance of some green spaces in Kumasi.

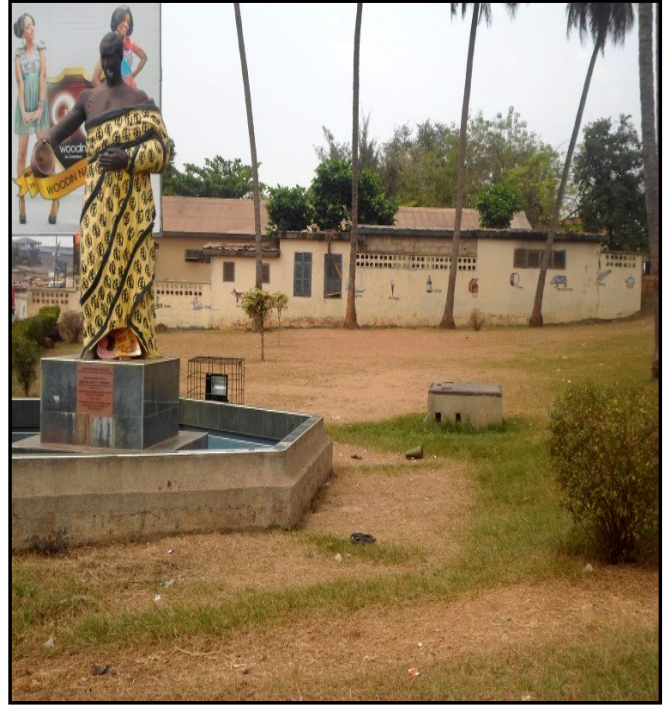

Abbey's Park

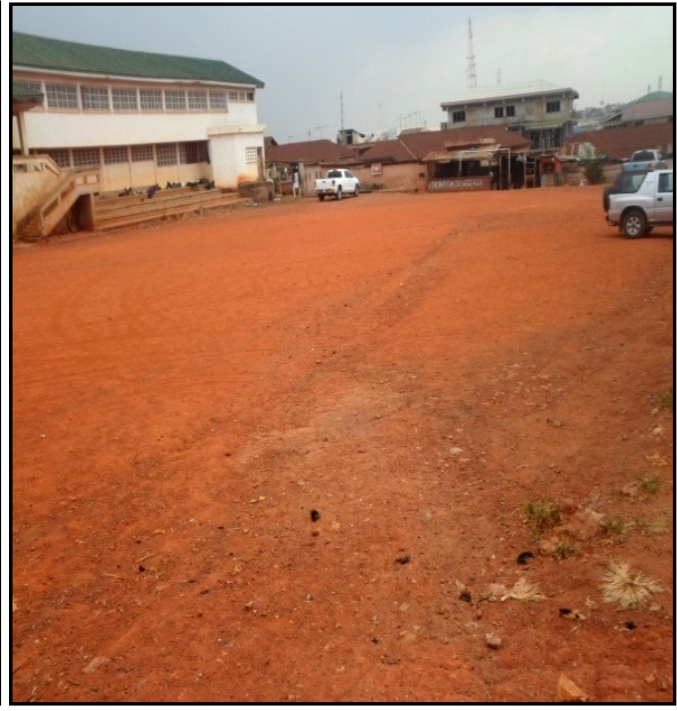

Fante Newtown Park

Fig. 5 - The level of maintenance of green spaces in Kumasi Source: Author's fieldwork (2013)

Responses by selected opinion leaders provided much evidence on the widespread poor maintenance of green spaces in Kumasi. For example, one opinion leader remarked as follows:

The Kumasi Children's Park is not functioning again as it has lost all its facilities due to lack of maintenance. Most of the facilities in Kumasi Zoo are very old and need to be replaced but nobody cares about it. In addition to this, the Ridge Park and the Fante Newtown Park are also losing their facilities due to poor maintenance (Key informant, Ahodwo Neighbourhood, IDI: 11/12/2012).

This comment does not only paint a bad picture about how green spaces are suffering from poor maintenance but it also gives an idea about how such spaces are not recognized as important resources in Kumasi. The lack of financial commitments towards the maintenance of green spaces was the substantive factor found behind the poor maintenance. It came out that 
the Kumasi city authorities do not have stable funds allocated for the maintenance of green spaces due to financial constraints. These revelations on poor maintenance from the study confirmed the findings of the 2012 Global Garden Report which pointed out poor maintenance as a devastating problem that is undermining the growth of green spaces in cities worldwide (Husqvarna Group 2012). Apart from financial hardships, the poor culture of maintenance was also found to hinder the maintenance of such spaces. In Kumasi and Ghana as a whole, it was observed that the frequent maintenance of facilities on public spaces is not a habit of the city authorities or other allied bodies. Even if the will is there, facilities on public spaces are often allowed to break down for a long period of time before actions are undertaken to remedy the situation. It has therefore become a practice of the city authorities of not regularly undertaking maintenance works on green space facilities. This habit does not only deny the green spaces of the needed maintenance works they require but it also make such places especially parks to lose their facilities that visitors can comfort themselves with, hence creating some link between the maintenance and the comfort themes.

\section{Comfort, safety and publicity of green spaces}

One of the fundamental goals of creating parks and other green spaces is to create spaces that people can rely on to enjoy and comfort themselves as indicated by Fredrick Law Olmsted who is often referred to as "the father of parks" (Shan 2009). However, for such comfort to be realized some facilities ought to be in place and maintained regularly. Critical among these facilities are seats, toilet facilities, and playing facilities (Dunnett et al. 2002, Corner et al. 2006). Inadequate facilities in parks were a critical problem in Kumasi. The residents and opinion leaders said categorically that the lack of facilities such as seats, playing facilities and toilet facilities make them feel uncomfortable visiting many parks in Kumasi and hence deter them from using such places. They also added the noisy condition of some parks as another major issue that hinders their level of comfort on green spaces in the area. Table 3 provides an overview of the respondent's assessment of the level of comfort in some parks and gardens in Kumasi.

\begin{tabular}{|llllll|}
\hline & \multicolumn{5}{c}{ Facilities } \\
& Seats & Playing fac. & Toilet fac. & Serene envt. \\
\cline { 2 - 5 } Adehyeman Gardens & Available & Available & Available & Bad \\
Kumasi Children's Park & Available & Absent & Absent & Bad \\
Ridge Park & Absent & Available & Absent & Bad \\
Parks and Gardens (Patasi) & Absent & Absent & Absent & Bad \\
Fante Newtown (Park) & Absent & Absent & Absent & Bad \\
Kumasi Zoo & Available & NA* & Available & Bad \\
Abbey's Park & Absent & Absent & Absent & Bad \\
KNUST Botanical & Available & Absent & Absent & Good \\
Gardens & & & & \\
\hline
\end{tabular}

* NA: Not Applicable

Source: Author's fieldwork (2013) 
Personal observations affirmed the respondents' claims. Many of the green spaces lacked basic facilities such as seats and playing facilities. In some of the parks that had seats such as Kumasi Zoo and Kumasi Children's Park, the conditions of the seats were poor. The problem of noise in the parks was worrying as most of the parks were located in commercial areas and along busy roads. For example, the Adehyeman Gardens, Kumasi Zoo, Fante Newtown Park and Abbey's Park were all located at the heart of the CBD where noise from industries, vehicles and other commercial activities were very prevalent. Other parks such as Kumasi Children's Park, Ridge Park, and Parks and Gardens at Patasi Neighbourhood were also located along busy roads. The loud noises in the parks prevent visitors from having quiet time to reflect on their wellbeing and also reduce stress. Lack of seats in the parks was equally a big problem in Kumasi because seats are basic facilities that parks are expected to have. Studies in some African cities such as Nairobi (Makworo and Mireri 2011) and Kisumu (Rabare et al. 2009) produced similar results with lack of seats found as a common problem of many urban parks. This problem denies visitors the opportunity to sit and chat with friends or read materials which are among the common activities that take place in parks.

Related to the level of comfort on green spaces in Kumasi was the issue of safety or security that received attention in the study. Studies show that the level of safety influences visitors decisions in choosing and using green spaces such as parks and gardens because many visitors want places that they will feel comfortable and safe from criminal activities (Ward et al. 2010). Cases of snatching of bags, mobile phones, undue attacks by criminals, and no lights on parks at night were the major misgivings that were highlighted in the focus group discussions. For example, one of the focus group participants said this:

My friend's mobile phone and bag were snatched from her at Abbey's park some months ago when she was using the park as a walkway to her house. I have also been personally attacked by criminals at Fante Newtown Park before (Community member, Nhyiaso Neighbourhood, FGD: 12/02/2013)

The theft and crime issues put fear in many of the park users especially those who use the parks as walkways at night. Worsening the security conditions of the parks was an isolated case of murder that was reported on one of the parks. One participant narrated:
It is not advisable for anybody to use the Kumasi Children's Park at night because of poor security reasons and absence of light. The park is now a home for criminals and a lot of criminal activities take place there. Even about two weeks ago a student of Kumasi Polytechnic was killed in the park (Community member, Amakom, FGD: 13/01/2013)

The above comments show how using some parks in Kumasi can be horrifying and insecure especially at night. This supports the assertion of Baycan-Levent et al. (2009) that green spaces can be a place for criminal activities especially at night and a home for the homeless. The finding also corroborates with studies in Bari (Italy), and Philadelphia (USA) where unsafe conditions of green spaces due to criminal activities emerged as a problem (Ho et al. 2005, Sanesi and Chiarello 2006). There was a lack of first aid and security guards on all the parks but they did not receive comments from the city authorities, opinion leaders and other allied bodies on green spaces. This might be due to the fact that such supplies are not considered as important resources that can help to enhance the safety of parks and gardens. The absence of light in the parks at night was found to limit the time visitors can spend in the parks and also motivate the criminal activities in the parks. At night, it creates a dark atmosphere for criminals to operate in the parks unnoticed. A similar finding came up in a study at Guangzhou (China) where darkness of parks was found to cause problems to park visitors (Jim and Chen 2006). The poor safety condition of the green spaces together with the unsatisfactory findings on the 
comfort, attractiveness, maintenance and accessibility themes already discussed above had consequences on the publicity of green spaces in Kumasi. They made it difficult for much publicity to be giving to the green spaces because there are not enough good features to market the green spaces on.

The publicity of green spaces does not only enhance the number of visits to these places but it has been identified by Konijnendijk (2010) as a useful tool that helps to brand cities as green cities or garden cities. Such branding evokes positive acclamations for a city such as good and healthy living environment. In Kumasi, the Kumasi Metropolitan Assembly (KMA) is supposed to promote the green spaces through mediums such as websites, leaflets on parks and gardens, and the media especially through radio, television and newspapers because of their wider coverage and large followers. A representative from the KMA through in-depth interview said that none of the parks and gardens has a website or leaflet to provide information to the general public. He pointed out further that for quite a long time his outfit has not been able to promote any park or garden through media advertisements to make such places well-known due to paucity of resources, especially lack of funds.

It came out that Kumasi Zoo, Adehyeman Gardens and Kumasi Children's Park have lost the publicity they enjoyed in the past on radio due to poor condition of these places. Out of the numerous parks in Kumasi, Ridge Park was the only park that both the KMA and the officials from the media confirmed to have some publicity by the way of advertisements on the radio and this was due to some social events that are organised there. The low publicity of the green spaces makes the general public and visitors to have little information about the green spaces which negatively affect the visits to such places.

\section{Conservation and heritage, and community participation themes}

The conservation and heritage theme was one particular theme that had some positive responses from the respondents. These positive responses stemmed from green spaces in Kumasi helping to preserve monuments of great personalities of the Ashanti Kingdom to monuments bearing some cultural features of the "Ashantis" who are the indigenes of Kumasi (Fig. 6). For example, green spaces at some roundabouts such as "Suame" Roundabout and "Santasi" Roundabout had the monuments of Opoku Ware II and Osei Tutu I respectively. These were great kings of the Ashanti Kingdom. The "Gee" Roundabout, "Kejetia" Roundabout, Prisons Roundabout and some reserved lawns in the CBD also received much commendation from the study participants for having statues of key personalities and cultural symbols of the Ashanti Kingdom (example the Golden stool). The Kumasi Children's Park was also observed to contain the statue of the reigning queen mother of the Ashanti.

Although these monuments on roundabouts and lawns at the CBD in Kumasi help to preserve some cultural heritage, their focus was narrow and it was not exploited very much by visitors. They are concentrated on minor green spaces such as roundabouts and lawns, and centred greatly on statues. As a result of this they do not receive much patronage from visitors. This is contrary to the findings of the 2012 World Cities Culture Report where many urban green spaces such as parks across the world were found to receive many visitors due to a variety of cultural heritage these spaces preserve (BOP Consulting 2012). In terms of conservation of wildlife (plant and animal species), officials from the Wildlife Division, Environmental Protection Agency and the Forest Service Division in Kumasi rated the condition of green spaces in Kumasi as average. They cited Kumasi Zoo, Kumasi Children's Park and patches of forests at Nhyiaso, Danyame and Ridge neighbourhoods as some of the green spaces that harbour varieties of plant and animal species. 


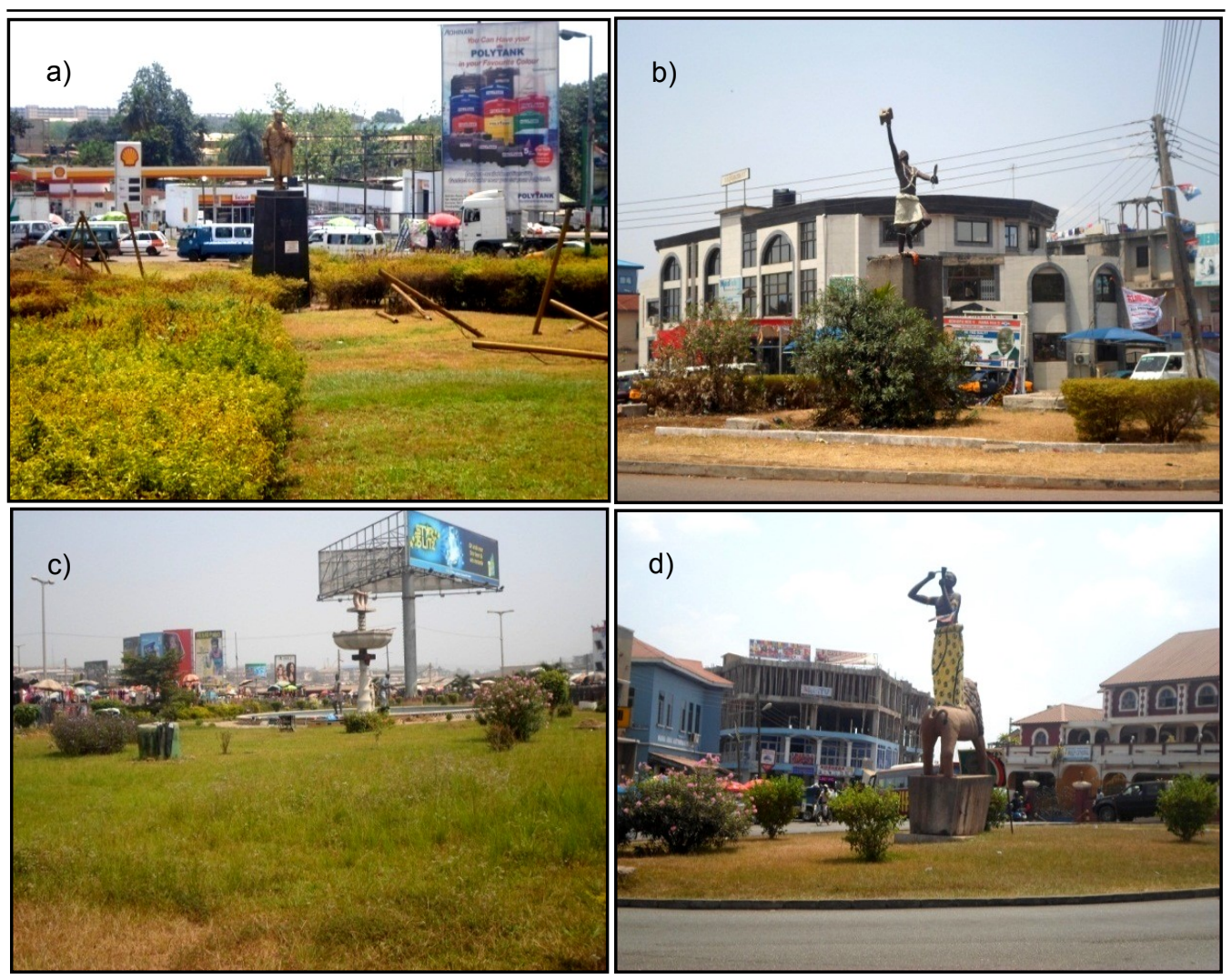

Fig. 6-Green spaces showing forms of cultural heritage at Kumasi Source: Author's Fieldwork (2013)

(a) A monument of Opoku Ware II at "Suame" Roundabout. (b) A monument of Okomfo Anokye at "Gee" Roundabout. (c) A monument of the Ashanti's golden stool at "Kejetia" Roundabout. (d) A man in a traditional cloth of the Ashanti's at Prison's Roundabout

Closely associated with the conservation and heritage theme was the community participation in the management of green spaces in Kumasi. Studies show that community participation enhances conservation of green spaces and it also promotes community stewardship for green spaces (Enger 2005, CABE 2010). This theme looked at community participation from the viewpoint of direct involvement of neighbourhoods in the preservation of green spaces in their areas. The study neighbourhoods were not adequately consulted and informed on matters concerning green spaces by the city authorities. They were also not actively involved in the decision making process, and not empowered to self-facilitate initiatives to enhance green spaces because they were considered not to have the necessary expertise to undertake such tasks by the city authorities. One of the residents had this to say:

I grew up in this neighbourhood and I have lived here all my life but I have never seen any group or residents of this neighbourhood been involved in green space preservation especially the Kumasi children's Park we have in this neighbourhood. The Kumasi Metropolitan Assembly does not regard us as important stakeholders, they do everything on their own and 
neglect the participation of this neighbourhood (Key informant, Amakom Neighbourhood, IDI: 14/03/2013).

The comment from this respondent show that the Kumasi city authorities tend to solely take initiatives and decisions on green spaces without the involvement of the local people who are also important stakeholders in the management of green spaces. This brings into play an element of autocratic governance practice adopted by the city authorities to manage green spaces. This became much clearer with the views of another respondent which is captured below.

We, the community members, can help to preserve and maintain green spaces in this area. Instead of the city authorities to involve us in such activities they always sideline us and go on with their own initiatives on the green spaces (Community member, Patasi Neighbhourhood, FGD: 26/02/13).

The above comments show that the Kumasi city authorities value less the inputs and the benefits that the participation of the local people can bring to conserve the green spaces. The foregoing gives a clear picture of poor community participation in the management of green spaces in Kumasi. Similar findings came up in a study by Fuwape and Onyekwele (2011) which found poor community participation in green space management as a common problem in many West African cities. Conversely, in many European cities, especially cities in UK, residents and community groups are highly recognised by local city authorities and involved in the conservation of green spaces (CABE 2010).

\section{Conclusions}

This paper has shown how the green spaces in Kumasi are in poor condition. Apart from the conservation and heritage theme, the performance of the green spaces on the other seven themes (attractiveness, comfort, safety, publicity, maintenance, community participation and accessibility) was poor. The paper concludes that multiplicity of themes or factors come together to enhance the state of green spaces, and that each of the themes needs attention due to some interdependencies that exist between them. For example, some relationships were observed to exist between maintenance and attractiveness themes, and comfort and safety themes. Conservation and heritage, and community participation themes also related very well. This suggests that keeping green spaces in good state demands broader attention as failure to do so may hinder the overall state of such spaces. Hence for cities to have good conditioned green spaces local city authorities must not be much selective in constraining their efforts to only one or two themes to the neglect of other themes since such decisions put the overall state of green spaces at risk. This extends the ideas expressed by Dunnet et al. (2002), Gobster and Westphal (2004), and other scholars who believe that the state of green spaces should not only be based on accessibility to such spaces but on an array of features that cover broader issues affecting the condition of green spaces in a given area.

It was revealed that the poor state of green space in Kumasi is primarily a result of underlying factors such as lack of priority to green spaces by the city authorities, poor culture of maintenance, uncooperative attitudes of the general public in conserving such spaces, lack of community participation and institutional inefficiencies. The general poor state of urban green spaces in Kumasi and its underlying factors therefore provide some lessons for other African cities where statistics show that green spaces are under severe threat. These lessons include prioritising green spaces in all development plans. The preparation of such development plans must take into account allocating specific areas for green spaces and such spaces protected against population growth and human activities. The poor maintenance culture should not be 
encouraged. Agencies managing green spaces have to be well-resourced in terms of funds and equipment to perform regular maintenance works on green spaces. Specific budgetary allocations from the government can annually or quarterly be made available for such maintenance works. In addition to this, funds from the private sector and benevolent organisations can also be sought.

Another factor that requires much attention is the uncooperative attitude of the general public towards the management of green spaces. This can be addressed by local city authorities running educational programmes in a form of community seminars and workshops to educate the public on the importance of green spaces and the need to preserve such spaces. This sensitisation will make the public to appreciate green spaces and to refrain from activities that destroy these spaces. Lastly, a collaborative governance approach must be adopted to manage green spaces. The planning, implementation and management of green spaces should not only be engineered by city authorities but by wider stakeholder organisations including the private sector and especially the general public. This will make such organisations to feel part of the management process and therefore to actively participate in conserving green spaces.

\section{References}

ABEGUNDE A. A., OMISORE E. O., OLUODO O. F, OLALEYE D. (2009), Commercial horticultural practice in Nigeria: Its socio-spatial effects in Lagos city, African Journal of Agricultural Research 4 (10), 1064-1072.

ABKAR M., MUSTAFA KAMAL M. S., MARIAPAN M., MAULAN S., SHEYBANIC M. (2010), The role of urban green spaces in mood change, Australian Journal of Basic and Applied Sciences 4 (10), 5352-5361.

ADAMS L. W., LEEDY D. L. (eds.) (1987), Integrating man and nature in the metropolitan environment: proceedings of a national symposium on urban wildlife, 4-7 November 1986, Chevy Chase, Maryland, National Institute for Urban Wildlife, Columbia, MD.

ADARKWA K. K., OWUSU-AKYAW K. (2001), Development control in Kumasi, in: Adarkwa K. K., Post J. (eds.), The fate of the tree: Planning and managing the development of Kumasi, Ghana, Woeli Publishing Services, Accra, pp. 199-208.

ADJEI MENSAH C. (2014a), Urban green spaces in Africa: Nature and challenges, International Journal of Ecosystem 4 (1), 1-11.

ADJEI MENSAH C. (2014b), Is Kumasi still a garden city? Land use analysis between 1980-2010, Journal of Environment and Ecology 5 (2), 89-107.

BARBOSA O., TRATALOS J. A., ARMSWORTH P. R., DAVIES R. G., FULLER R. A., JOHNSON P., GASTON K. J. (2007), Who benefits from access to green space? A case study from Sheffield, UK, Landscape and Urban Planning 83 (2-3), 187-195.

BAYCAN-LEVENT T., NIJKAMP P. (2009), Planning and management of urban green spaces in Europe: Comparative analysis, Journal of Urban Planning and Development 135 (1), $1-12$.

BAYCAN-LEVENT T., VREEKER R., NIJKAMP P. (2009), A multi-criteria evaluation of green spaces in European cities, European Urban and Regional Studies 16 (2), 193-213.

BOLNICK J., KAYUNI H. M., MABALA R., MCGRANAHAN G., MITLIN D., NKHOMA S., OUCHO J., SABRI A., SABRY S., SATTERTHWAITE D., SWILLING M., TACOLI C., TAMBULASI R. I. C., VAN DONK M. (2006), A pro-poor urban agenda for Africa: Clarifying ecological and development issues for poor and vulnerable populations, International Institute for Environment and Development, London. London.

BOP CONSULTING (2012), 2012 World cities culture reports, Mayor of London,

CABE (2010), Community-led spaces: A guide for local authorities and community groups, CABE, London.

CENTRE FOR URBAN \& REGIONAL ECOLOGY (2002), Developing standards for 
accessible natural greenspace in towns and cities, University of Manchester, Manchester. COBBINAH P. B., DARKWAH R. M. (2016), African urbanism: the Geography of urban greenery, Urban Forum 27 (2), 149-165.

CORNER D., BARNARD P., EVANS T., HYDE P., PERRYMAN S. (2006), Enhancing urban green space, National Audit Office, London.

DESOUZA K. C., FLANERY T. H. (2013), Designing, planning, and managing resilient cities: A conceptual framework, Cities 35, 89-99.

DUNNETT N., SWANWICK C., WOOLLEY H. (2002), Improving urban parks, play areas and green spaces, Department for Transport, Local Government and the Regions, London.

ENGER S. C. (2005), Planning for parks, recreation, and open spaces in your community, Washington State Department of Community, Trade and Economic Development, Washington, D.C.

FRASER E. D. G. (2002), Urban ecology in Bangkok, Thailand: Community participation, urban agriculture and forestry, Environments 30 (1), 37-49.

FUADY M., DARJOSANJOTO E. T. S. (2012), Tropical ecological city concept for Banda Aceh to become sustainable after tsunami disaster, Journal of Applied and Environmental and Biological Sciences 2 (8), 428-433.

FULLER R. A., GASTON K. J. (2009), The scaling of green space coverage in European cities, Biology Letters 5 (3), 352-355.

FUWAPE J. A., ONYEKWELU J. C. (2011), Urban Forest Development in West Africa: Benefits and Challenges, Journal of Biodiversity and Ecological Sciences 1 (1), 77-94.

GEURTS E. (2009), Working on cities: An experience from Kumasi, Ghana. A Design

Studio for Architects and Urban Management Students, The Institute for Housing and urban development Studies (IHS), Rotterdam.

GHANA STATISTICAL SERVICE (2012), 2010 Population and housing census final results, Ghana Statistical Service, Accra.

GOBSTER P. H., WESTPHAL L. M. (2004), The human dimensions of urban greenways: planning for recreation and related experiences, Landscape and Urban Planning $68(2-3), 147-165$.

GODEFROID S. (2001), Temporal analysis of the Brussels flora as indicator for changing environmental quality, Landscape and Urban Planning 52 (4), 203-224.

GOMES C. S., MORETTO E. M (2011), A framework of indicators to support urban green area planning: a Brazilian case study, Proceedings of the International Academy of Ecology and Environmental Sciences 1 (1), 47-56.

HANCOCK D. R., ALGOZZINE B. (2006), Doing case study research: A practical guide for beginning researchers, Teachers College Press, New York.

HARNIK P. (2004), The excellent city park system: What wakes it great and how to get there? The Trust for Public Land, San Francisco, CA.

HO C.-H., SASIDHARAN V., ELMENDORF W., WILLITS F. K., GRAEFE A., GODBEY

G. (2005), Gender and ethnic variations in urban parks preferences, visitation, and perceived benefits, Journal of Leisure Research 37 (3), 281-306.

HOWARD E. (1902), Garden cities of to-morrow, Swan Sonnenschein \& Co., London. HUSQVARNA GROUP (2012), Global garden report 2012: A closer look at urban green spaces around the globe, Retrieved from: http://www.husqvarnagroup.com/. JABAREEN Y. R. (2006), Sustainable urban forms: Their typologies, models, and concepts, Journal of Planning Education and Research 26, 38-52. JIM C. Y. (2004), Green-space preservation and allocation for sustainable greening of compact cities, Cities 21 (4), 311-320. JIM C. Y., CHEN W. Y. (2006), Perception and attitude of residents towards urban green spaces in Guangzhou (China), Environmental Management 38 (3), 338-349. JOHNSTON J. (1990), Nature areas for city people. Ecology Handbook, London Ecology Unit, London. KITHIIA J., LYTH A. (2011), Urban wildscapes and green spaces in Mombasa and their 
potential contribution to climate change adaptation and mitigation, Environment and Urbanization 23 (1), 251-265.

KONIJNENDIJK C. C. (2010), Green cities, competitive cities - Promoting the role of green space in city branding, Paper presented at IFPRA World Congress, Hong Kong, China.

KUCHELMEISTER G. (1998), Urban forestry in the Asia-Pacific region: status and prospects, FAO Asia-Pacific Forestry Sector Outlook Study Working Paper Series No: 44, Retrieved from: http://www.fao.org/.

LAFORTEZZA R., CARRUS G., SANESI G., DAVIES C. (2009), Benefits and well-being perceived by people visiting green spaces in periods of heat stress, Urban Forestry \& Urban Greening 8 (2), 97-108.

Economist Intelligence Unit (2011), Africa green city index. Assessing the environmental performance of Africa's major cities, Siemens AG, Munich.

MACCONNACHIE M. M., SHACKLETON C. M., MCGREGOR G. K. (2008), The extent of public green space and alien plant species in 10 small towns of the Sub-Tropical Thicket Biome, South Africa, Urban Forestry and Urban Greening 7 (1), 1-13.

MAKWORO M., MIRERI C. (2011), Public open spaces in Nairobi City, Kenya, under threat, Journal of Environmental Planning and Management 54 (8), 1107-1123.

MARCOTULLIO P. J. (2001), Asian urban sustainability in the era of globalization, Habitat International 25 (4), 577-598.

MILLS A. J., DUREPOS G., WIEBE E. (2010), Encyclopedia of case study research, Sage Publications, Thousand Oaks.

MINISTRY OF LANDS AND NATURAL RESOURCES (2010), Land administration project II: Proposed office building in Kumasi, Ministry of Lands and Natural Resources, Accra. NYANTAKYI-FRIMPONG H., ARKU G., INKOOM D. K. B. (2016), Urban agriculture and political ecology of health in municipal Ashaiman, Ghana, Geoforum 72, 38-48.

ODUWAYE L. (2013), Globalization and urban land use planning: The case of Lagos,

Nigeria, Proceedings REAL CORP 2013 Tagungsband, Retrieved from: http://www.corp.at/. QUAGRAINE V. K. (2011), Urban landscape depletion in the Kumasi Metropolis, in: Adarkwa K. K. (ed.), Future of the tree. Towards growth and development of Kumasi, University Printing Press, Kumasi, pp. 212-233.

PAULEIT S., SLINN P., HANDLEY J., LINDLEY S. (2003), Promoting the natural greenstructure of towns and cities: English nature's accessible natural green space standards models, Built Environment 29 (2), 157-170.

PLYMOUTH CITY COUNCIL (2009), Plymouth's green space strategy 2008 - 2023, Plymouth City Council, Plymouth.

RABARE R. S., OKECH R., ONYANGO G. M. (2009), The role of urban parks and socio -economic development: Case study of Kisumu Kenya, Theoretical and Empirical Researches in Urban Management 3 (12), 22-36.

SANESI G., CHIARELLO F. (2006), Residents and urban green spaces: the case of Bari, Urban Forestry \& Urban Greening 4 (3-4), 125-134.

SHAN X. (2009), Urban green spaces in Guangzhou (China): attitude, preference, use pattern and assessment, PhD thesis, University of Hong Kong, Retrieved from: http://hub.hku.hk/handle/10722/57034.

SINGH V. S., PANDEY D. N., CHAUDHRY P. (2010), Urban forests and open green spaces: Lessons for Jaipur, Rajasthan, India, RSPCB Occasional Paper No. 1, 1-22.

STANNERS D., BOURDEAU P. (1995), The urban environment, in: Stanners D., Bourdeau P. (eds.), Europe's environment - The Dobris Assessment, European Environment Agency, Copenhagen, pp. 261-296.

SUKOPP H., NUMATA M., HUBER A. (1995), Urban ecology as the basis of urban planning, SPB Academic Publishing, Amsterdam.

TONTOH A. G. (2011), A study to ascertain the growth situation of the Kumasi Metropolitan area (KMA): A remote sensing approach, Master's thesis, Kwame Nkrumah University of Science and Technology, Kumasi, Retrieved from: http://ir.knust.edu.gh/xmlui/ 
handle/123456789/472.

THE URBAN GREEN SPACES TASKFORCE (2002), Green spaces, better places (final report), Department for Transport, Local Environment and the Regions, London.

UNITED NATIONS (2008), World urbanization prospects. The 2007 revision, United Nations, New York, Retrieved from: http://www.un.org/.

UNITED NATIONS (2012), World urbanization prospects. The 2011 revision, United Nations, New York, Retrieved from: http://www.un.org/.

URGE-TEAM (2004), Making greener cities - A practical guide, UFZ Centre for Environmental Research, Leipzig-Halle, Retrieved from: www.urge-project.org.

VAN HERZELE A., WIEDEMANN T. (2003), A monitoring tool for the provision of accessible and attractive urban green spaces, Landscape and Urban Planning 63 (2), 109-126.

WANG X.-J. (2009), Analysis of problems in urban green space system planning in China, Journal of Forestry Research 20 (1), 79-82.

WARD C. D., PARKER C. M., SHACKLETON C. M. (2010), The use and appreciation of botanical gardens as urban green spaces in South Africa, Urban Forestry \& Urban Greening $9(1), 49-55$.

WILLIAMS K., GREEN S. (2001), Literature review of public space and local environments for the cross cutting review: Final report, Communities and Local Government, Retrieved from: http://eprints.uwe.ac.uk/10358.

YIN R. K. (2003), Case study research: Design and methods, Sage Publications, Thousand Oaks.

Initial submission: 07.10.2016

Revised submission: 13.12 .2016

Final acceptance: 20.12 .2016

Correspondence: Department of Geography and Regional Planning, University of Cape Coast, University Avenue 1, Cape Coast, Ghana

Email: cmensah@ucc.edu.gh 
